\title{
New Distributional Records of Cleome chelidonii L.f. and Cleome rutidosperma DC. (Cleomaceae) in Madura Island
}

\author{
ARIFIN SURYA DWIPA IRSYAM ${ }^{1 *}$, MUHAMMAD RIFQI HARIRI ${ }^{2}$, ASHARI BAGUS \\ SETIAWAN $^{3}$, RINA RATNASIH IRWANTO ${ }^{4}$, ASIH PERWITA DEWI $^{5}$ \\ ${ }^{1}$ Herbarium Bandungense (FIPIA), School of Life Sciences and Technology (SITH), Institut Teknologi Bandung \\ Labtek VC Building, Jl. Let.Jen.Purn.Dr (HC) Mashudi No. 1 Jatinangor, West Java, Indonesia. 45363 \\ *Email: arifin@sith.itb.ac.id \\ ${ }^{2}$ Research Center for Plant Conservation and Botanic Gardens, Indonesian Institute of Sciences \\ Jln. Ir. H. Juanda No. 13 Bogor, West Java, Indonesia. 16003 \\ ${ }^{3}$ UPT. Laboratorium Terpadu, Universitas Trunojoyo Madura \\ Jl. Raya Telang PO BOX 2 Madura, East Java, Indonesia. 69162 \\ ${ }^{4}$ School of Life Sciences and Technology (SITH), Institut Teknologi Bandung \\ Labtek XI Building, Jl. Ganesha No. 10 Bandung, West Java, Indonesia. 40132 \\ ${ }^{5}$ Botany Division, Research Center for Biology, Indonesian Institute of Sciences \\ Jl. Raya Bogor KM 46 Cibinong, West Java, Indonesia. 16911 \\ Received 21 January 2020; Received in revised form 11 April 2020; \\ Accepted 17 May 2020; Available online 30 June 2020
}

\begin{abstract}
Calcareous soil and dry climate are characteristic of Madura Island, located on the east coast of Java, Indonesia. The group of flowering plants that adapted to these conditions is the genus Cleome L. (Cleomaceae). In 1963, Backer and Bakhuizen van den Brink Jr. only listed three species of Cleome from Madura, i.e., C. aspera J.König ex DC., C. gynandra L., and C. viscosa L. Since then, the updated data on the genus Cleome of Madura is not provided yet. Therefore, this study aimed to provide updated information on the genus in Madura island. The botanical exploration was conducted at Bangkalan, Sampang, Pamekasan, and Sumenep in December 2019 to January 2020. The two additional species, namely $C$. chelidonii L.f. and $C$. rutidosperma DC., were reported for the first time in Madura. Both species were considered as the newly distributional record for the island. Cleome chelidonii was found in Gapura Tengah (Sumenep Regency), and C. rutidosperma was collected from Kamal (Bangkalan Regency). The botanical information on both species is presented, including the updated key to the Cleome of Madura Island. This study provides updated information on genus Cleome in Madura and reporting the existence of Cleome chelidonii and Clome rutidosperma from the island. The presence of both species was considered as a newly distributional record.
\end{abstract}

Keywords: Cleomaceae; Cleome; Madura; spider flower; weeds

\section{INTRODUCTION}

Madura Island is located in the Northeastern part of Java, and it comprises an area of $4.382 \mathrm{~km}^{2}$ (Flathe \& Pfeiffer, 1963; Uhlig, 1980). Geologically, the island is a continuation of the limestone mountains from the Northern mainland of East Java (Rifai, 2007; Hefni, 2008). The significant parts of Madura island consist of limestone beds with typical karst (Flathe \& Pfeiffer, 1963; Uhlig, 1980; Spaggiari et al., 2018). This island also has a dry climate due to the monsoon winds (Rifai, 2007). These conditions cause the type of vegetation on Madura island is mixed monsoon forest (Backer \& Bakhuizen van den Brink, 1965; Rifai, 2007).
A few botanical research was conducted in Madura because the flora composition is still considered the same as the Eastern part of Java (Backer \& Bakhuizen van den Brink, 1965). This causes the information on flora Madura to have not been wholly recorded, and a specific book on Flora of Madura is not provided yet (Irsyam, 2015). The previous studies showed that several newly registered species had been reported from Madura, namely Citrus $\times$ floridana (J. Ingram \& H. Moore) Mabb. (Rutaceae) and Eleocharis acicularis (L.) Roem. \& Schult. (Cyperaceae) (Irsyam \& Chikmawati, 2015; Setiawan \& Ariyanti, 2018). 
Cleome is the largest genus in the Cleomaceae, and it comprises 207 species (Inda et al., 2008; Royal Botanic Gardens Kew, 2019). Morphologically, Cleome is characterized by its herbaceous habit, bisexual flowers, and dehiscent fruits with persistent replum (Inda et al., 2008; de Castro et al., 2014). The genus is distributed in the drier parts of tropics and subtropics (de Castro et al., 2014). Thus, Cleome can adapt to the drought environment (Backer \& Bakhuizen van den Brink, 1965; Koteyeva et al., 2011).

In the Flora of Java, there are only three species of Cleome that have been reported from Madura, i.e., Cleome aspera J.König ex DC., Cleome gynandra L., and Cleome viscosa L. (Backer \& Bakhuizen van den Brink, 1963). Since then, the updated information has not been provided. Therefore, the study aims to provide updated data on the genus Cleome in Madura. Furthermore, this study was also carried out as a part of the Flora of Madura treatment.

Our study revealed that two additional species were recently found in Madura: Cleome chelidonii L.f. and Cleome rutidosperma DC. The updated key to the genus Cleome of Madura, descriptions, photographs, and brief discussions are provided.

\section{MATERIALS AND METHODS}

The field study was carried out using an exploration method (Rugayah et al., 2004) in Bangkalan, Sampang, Pamekasan, and Sumenep from December 2019 to January 2020. The specimens were collected following van Balgooy (1987). The data recorded from the field includes the collection number, collector names, location, habitat, vernacular names, uses, and morphological characters.

Herbarium preparation followed Djarwaningsih (2002a; 2002b) and then deposited in Herbarium Bandungense (FIPIA), School of Life Sciences and Technology (SITH), Institut Teknologi Bandung (ITB). Herbarium studies were also carried out in Herbarium Bogoriense (BO), Herbarium Bandungense (FIPIA), and UPT. Laboratorium Terpadu Universitas Trunojoyo Madura.
The collected specimens were identified by comparing the specimens description to the previously published references for the genus Cleome (Woodson, 1948; Jacobs, 1960; Iltis, 1960; Backer and Bakhuizen van den Brink, 1963).

\section{RESULT AND DISCUSSION Taxonomic treatment.}

\section{Cleome chelidonii L.f.}

Suppl. Pl. 300 (1782)(Figure 1).

Synonym. Aubion chelidonii (L.f.) Raf., Sylva Tellur. 110 (1838); Cleome chelidonii var. pallae C.S.Reddy \& V.S.Raju, J. Econ. Taxon. Bot. 25: 217 (2001); Cleome leschenaultii Schult. \& Schult.f., Syst. Veg. 7: 49 (1829); Cleome schraderi Schult. \& Schult.f., Syst. Veg. 7: 48 (1829); Corynandra pulchella Schrad. ex Spreng., Syst. Veg. 4(2): 204 (1827). Vernacular names. Unrecorded.

Morphology. Herb, erect, up to $80 \mathrm{~cm}$ tall. Stem yellowish green, glabrous, lenticelled. Leaves 3-7-foliate, alternate; petiole slender, green, $1.8-2 \mathrm{~cm}$; petiolules very short, c. $2 \mathrm{~mm}$; leaflets elliptic-oblong to obovate, $1.4-3.1 \times$ $0.6-1 \mathrm{~cm}$, base cuneate, margin entire, apex acuminate, obtuse to mucronate, scabrous, covered by bulbous-hairs. Inflorescence raceme, axillary, flower bisexual; pedicels slender, 1.7-2.3 cm, reddish-green; sepals 4, alternate with petal, obovate, $4 \mathrm{~mm}$ long, yellowish-green; petals 4 , obovate-elliptic, 4$10 \times 2.5-5 \mathrm{~mm}$, clawed at tips, bright pink; stamens c. 52, free; filament filiform, white, broadened at tips, $10 \mathrm{~mm}$ long; anther yellow, basifixed, curved, c. $1 \mathrm{~mm}$ long; ovary superior, sessile, linear; stigma cup-shaped, yellowishgreen. Fruits capsule, linear, curved, 5.4-7.2 $\times$ $0.3 \mathrm{~cm}$, green, dehiscent. Seeds asymmetric, $c$. $2 \mathrm{~mm}$ wide, cleft open, warty, blackish.

Habitat. In Sumenep, Madura, the species grows in rice fields, open and wet areas on clay soil at $30 \mathrm{~m}$ asl.

Distribution. India, Sri Lanka, Indochina, and it also occurred in the Central part and Eastern part of Java island (Jacobs, 1960; Backer \& Bakhuizen van den Brink, 1963; Aparadh et al., 2012). In this study, the species has been observed in Madura island. 
Examined specimen. Rice field, Gapura Tengah, Gapura Subdistrict, Sumenep Regency, Madura island, East Java, 24 December 2019, ASD Irsyam, MR Hariri, AB Setiawan SUM-03 (FIPIA). Other specimens collected from Madura were not found at BO.

Cleome rutidosperma DC.

DC.Prod.1: 241 (1824)(Figure 2).

Synonym. Cleome ciliata Schumach. \& Thonn., Kongel. Danske Vidensk. Selsk. Naturvidensk. Math. Afh. 4: 67 1828; Cleome guineensis Hook.f., Niger Fl. 218 1849; Cleome rutidosperma var. hainanensis J.L.Shan, Bull. Bot. Res., Harbin 19: 126 1999; Cleome rytidosperma DC. ex Schult. f., Syst. Veg. 7(1): 4141 1829; Cleome thyrsiflora De Wild. \& T.Durand, Bull. Soc. Roy. Bot. Belgique Compt. Rend. 38: 141899.

Vernacular names. Bubhuan (Madura).

Morphology. Herb, erect, up to $80 \mathrm{~cm}$ tall. Stem angular, brownish-green, covered by bristles. Leaves 3-foliate, alternate; petiole slender, brownish-green to brown, $2.5-4.8 \mathrm{~cm}$, canaliculate; petiolules very short, $c .1 \mathrm{~mm}$; leaflets ovate to rhomboid or rhomboid-elliptic, $1.2-4.1 \times 0.6-2 \mathrm{~cm}$, base cuneate to asymmetric, margin entire, apex acute. Inflorescence raceme with reduced leaves, flower bisexual; peduncle filiform, up to $2.7 \mathrm{~cm}$ long, brownish-green; sepals 4 , alternate with petal, narrowly lanceolate, $4.5 \mathrm{~mm}$ long, brownish-green, covered by short bristles; petals 4 , narrowly elliptic, asymmetric, $12 \times 3$ $\mathrm{mm}$, lilac-blue and turning pink at maturity, two median petals with yellowish-white color at base; stamens 6, free; filament filiform, purplish at base, white at tips, 6-10 mm long, curved; anther blue, basifixed, c. $2 \mathrm{~mm}$ long; ovary superior, linear, curved; stigma cupshaped, green. Fruits capsule, linear, curved, 3.5-4.3 $\times 0.4 \mathrm{~cm}$, green, dehiscent. Seeds asymmetric, $c$. $1.5 \mathrm{~mm}$ wide, cleft open, ribbed, brown; elaiosome thin, white.

Habitat. In Bangkalan, Madura, the species grow in open areas and roadsides at $4 \mathrm{~m}$ asl.

Distribution. Western Africa (Guinea, Congo, and Angola). Later, the species was introduced to the Caribbean, Thailand, and the Malesia region (Iltis, 1960; Jacobs, 1960). In Madura, it was found from Telang, Bangkalan Regency.

Examined specimen. Telang village, Kamal Subdistrict, Bangkalan Regency, Madura island, East Java, 09 January 2020, $A B$ Setiawan 132 (FIPIA). Other specimens collected from Madura island were not found at BO.

An updated key to the genus Cleome of Madura (modified after Backer \& Bakhuizen van den Brink, 1963)

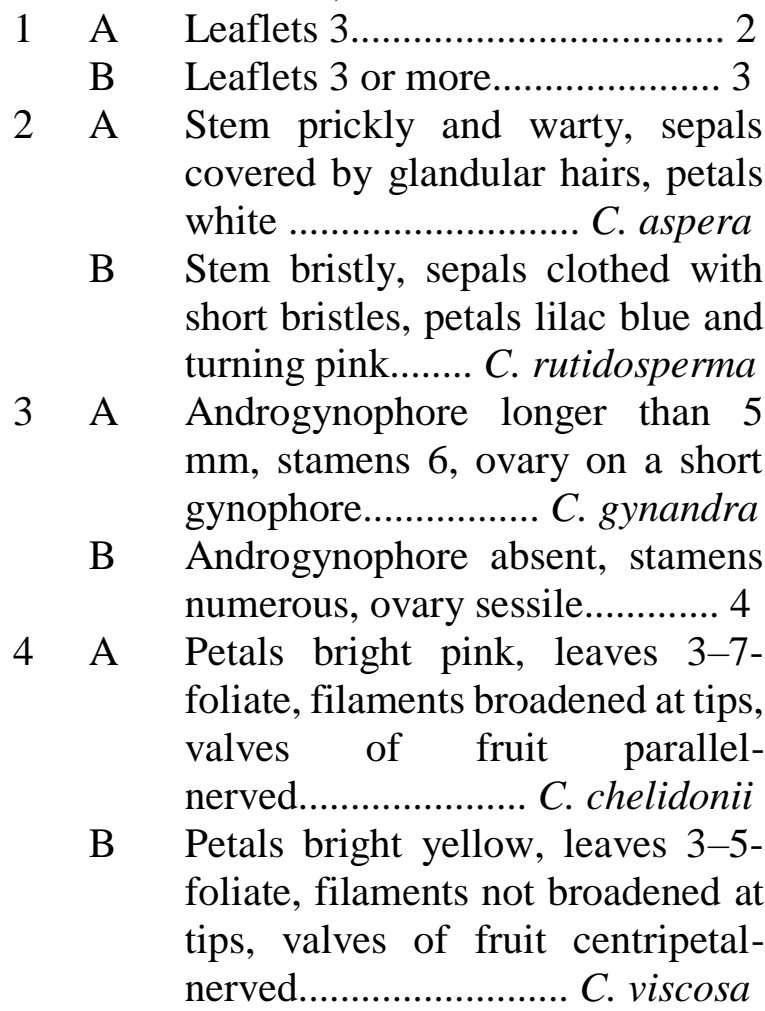

Previously, the genus Cleome was only represented by three species in Madura island, namely Cleome aspera J.Koenig ex DC., Cleome gynandra L., and Cleome viscosa L. (Backer \& Bakhuizen van den Brink, 1963). Yet, two additional species, Cleome chelidonii L.f. and Cleome rutidosperma DC., have been observed and collected during our botanical survey in Madura. Their presence in Madura has not been reported before, either by Jacobs (1960) or Backer \& Bakhuizen van den Brink (1963). Thus, Cleome chelidonii and Cleome rutidosperma can be considered a new distributional record to the Flora of Java. These findings added the number of Cleome of Madura into five species. 
Cleome chelidonii is an exotic species native to India and also distributed from Sri Lanka to Indochina (Jacobs, 1960; Aparadh et al., 2012). But, there is no information when it was first introduced to Java and Madura. In Java, it was only reported from Tegal to Pasuruan (Jacobs, 1960; Backer \& Bakhuizen van den Brink, 1963).
At the observation site, Cleome chelidonii abundantly grows in rice fields and watery places. Therefore, the dispersal of the seed is allegedly aided by water. In addition, the ripe fruits easily to break and throw the seeds away. Jacobs (1960) notes that the seeds do not have an elaiosome. Thus, the possibility of the seeds being spread by ants is very little.
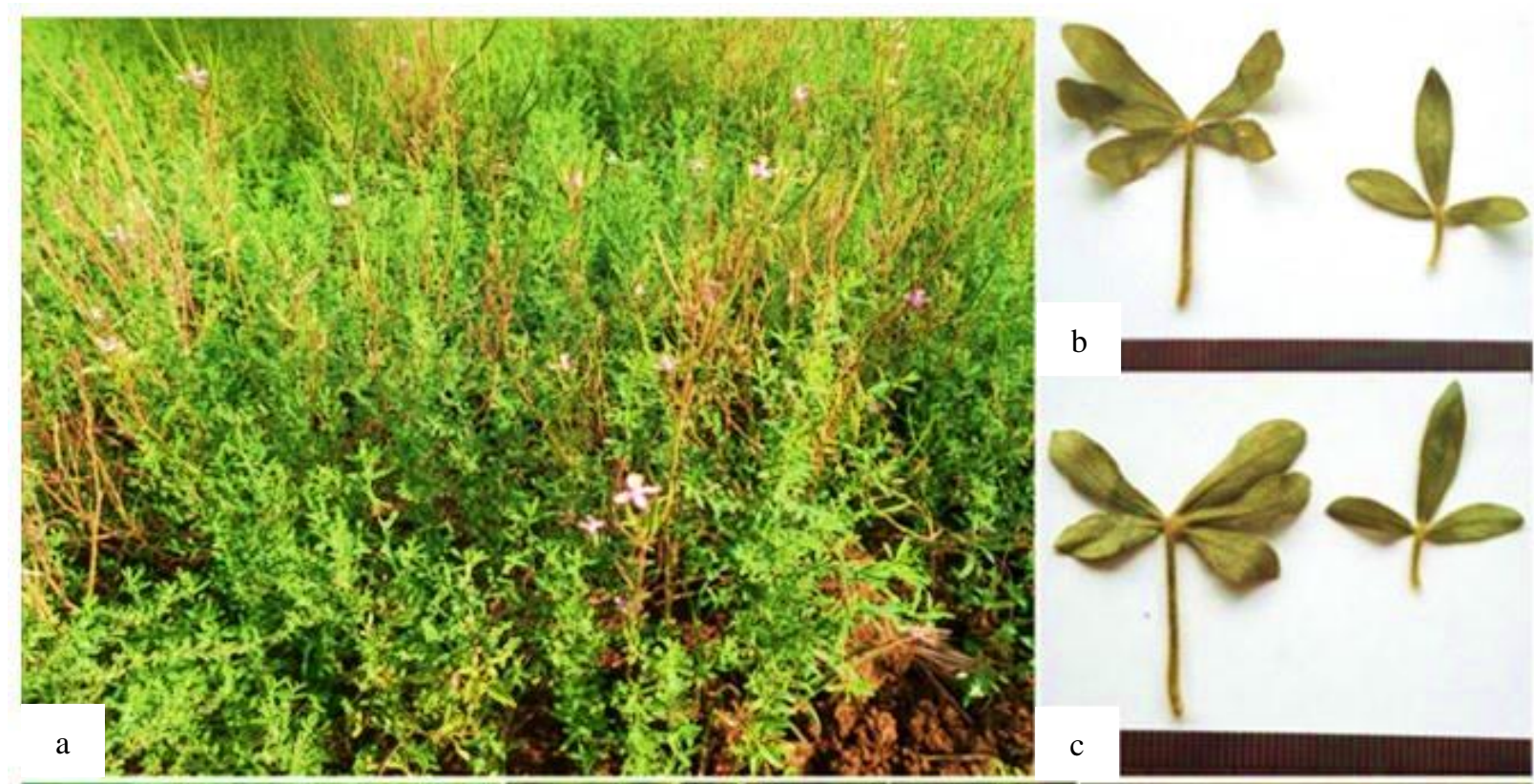

b
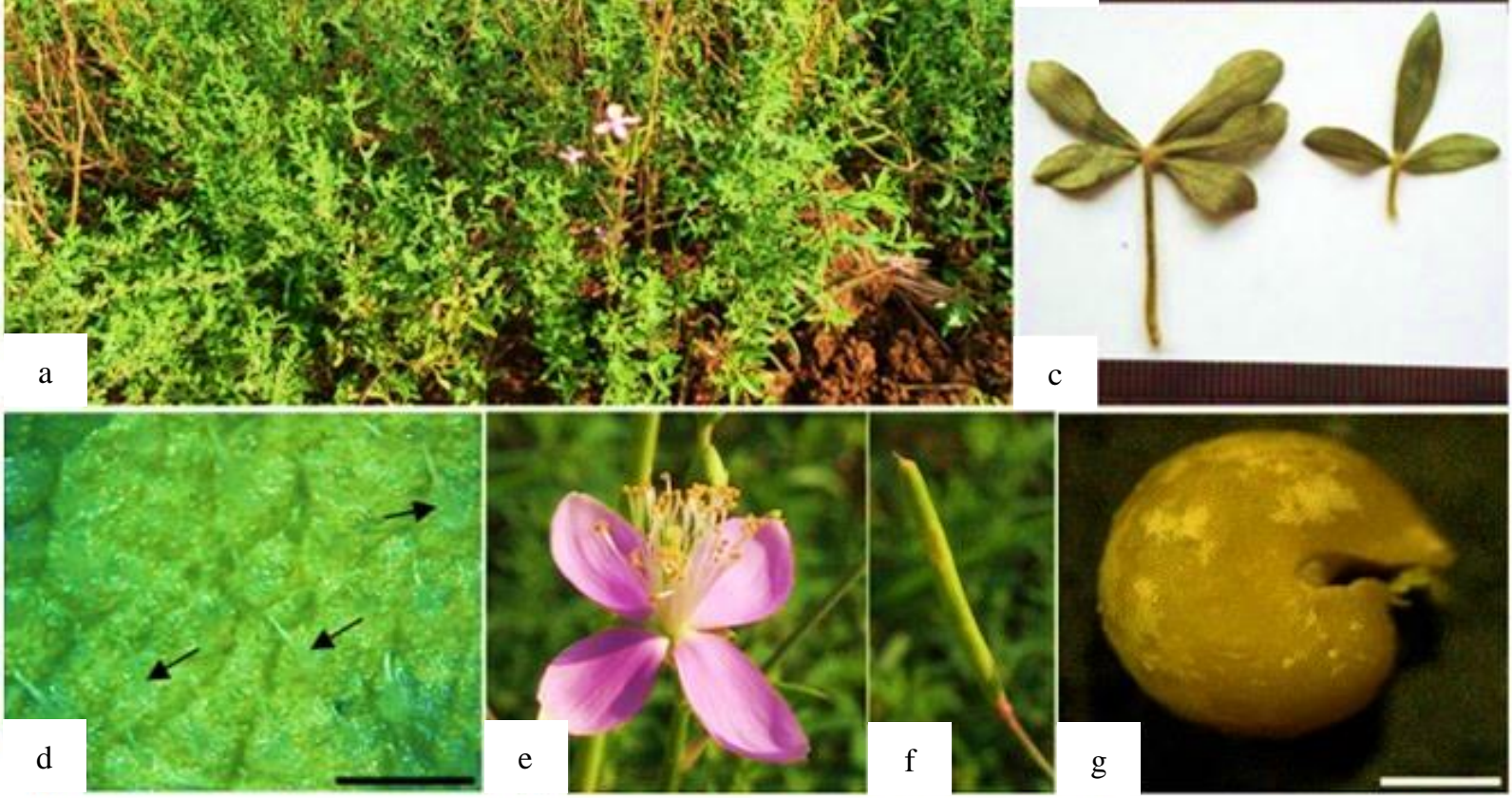

Figure 1. Cleome chelidonii L.f: a. habit; b. adaxial leaf surface; c. abaxial leaf surface; d. bulbous hairs (black arrows); e. flower; f. fruit; g. seed. Bar scale $=0.25 \mathrm{~mm}$.

Cleome chelidonii has been traditionally used as fodder by the local people in Gapura, Sumenep. Even so, the species has potential as a medicinal plant. Further pharmacological studies revealed that the methanol extract of $C$. chelidonii has antimicrobial, antiinflammatory, antinociceptive, and antipyretic activities (Parimalakrishnan et al., 2007; Sridhar et al., 2014). Moreover, the flavonoids isolated from the leaf extract were also observed to have hepatoprotective activity and cytotoxicity against the HepG2 human hepatoma cell line (Nguyen et al., 2017). 


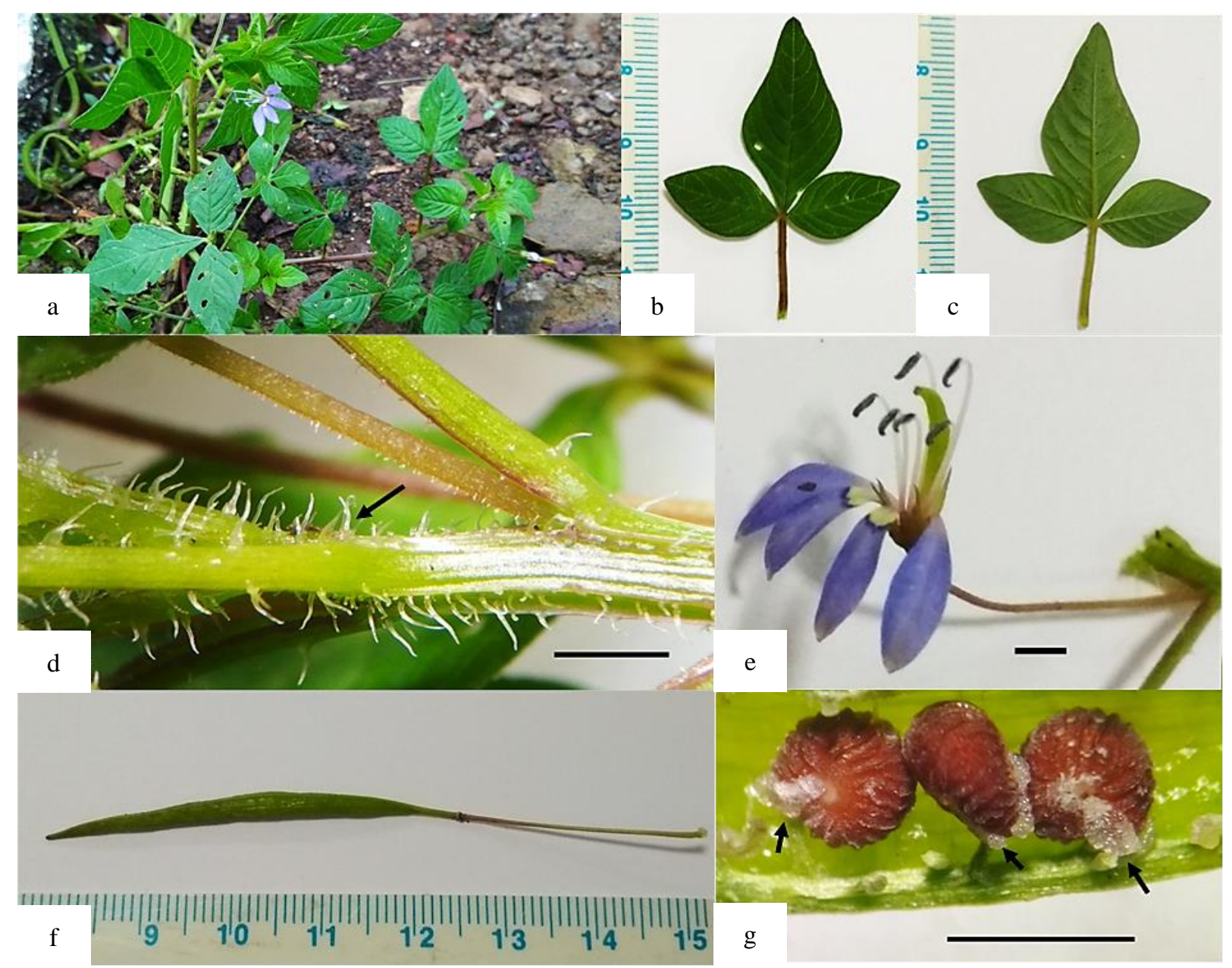

Figure 2. Cleome rutidosperma DC: a. habit; b. adaxial leaf surface; c. abaxial leaf surface; d. bristle hairs (black arrow); e. flower; f. fruit; g. seed with elaiosome (black arrows). Bar scale $=2 \mathrm{~mm}$.

Cleome rutidosperma is native to Western tropical Africa, and it was first discovered from Java (Tanjung Priok) in 1946 (Iltis, 1960; Jacobs, 1960). Later, it has been quickly spreading in Indonesia (Tjitrosoedirdjo et al., 2007). Yet, the information on Cleome rutidosperma in Madura is not clearly known until it was collected from Bangkalan in January 2020.

Cleome rutidosperma grows like weeds in Madura. The species are commonly found in open areas, abandoned areas, rice fields, and roadsides. The seed is small and has a fatty white elaiosome at the base (Figure $2 \mathrm{~g}$ ). This structure mediates myrmecochorous seed dispersal because it attracts ants to move the seeds from place to place.

Elaiosome is a lipid-rich appendage, sometimes also rich in protein or starch, used as food by ants (Van Der Pijl, 1972; Mayer et al., 2005). The ontogeny studies showed that the elaiosome develops very early from the external integument cells near the funicular and micropylar area of the seed (Ciccarelli et al., 2005). Other species of Carex have the elaiosome origin from the bracts surrounding the ovary (Handel, 1976). The ants eat the elaiosome without harming the seeds. It also helps the seeds germinate easily once the ants have removed the elaiosome (Forest \& Madden, 2011). The elaiosome also has other functions in the dormancy process and water reservation (Lisci et al., 1996).

The Madurese ethnic utilize the leaves of Cleome rutidosperma as a vegetable. The leaves are cooked into stir-fry and soup. Umiyah (2011) reported that the leaves also cooked into sayur asem and sayur bening. Moreover, the fresh leaves contain large nutritional properties, i.e., protein, fat, carbohydrates, fiber, calcium, magnesium, phosphorus, and iron (Leung et al., 1968). 
Cleome rutidosperma also contains chemical compounds that actively enhance wound healing and boost the immune system (Mondal \& Suresh, 2012; Arhoghro et al., 2014). Besides, the aqueous, methanolic, ethanolic, and ethyl-acetate extracts were observed to have antidiabetic, antineuroinflammatory, antinociceptive, and anticancer activities (Okoro et al., 2014; Okoro et al., 2015; Ding et al., 2016; Ansari et al., 2016; Prabha et al., 2017).

\section{CONCLUSION}

Cleome chelidonii and $C$. rutidosperma were considered as additional species to the Cleome of Madura. Their existence in Madura island has never been noted and published before. These findings increase the total number of Cleome species on the island into five species.

\section{ACKNOWLEDGEMENTS}

We thank the Head of Herbarium Bogoriense (BO) and the Head of UPT. Laboratorium Terpadu, Universitas Trunojoyo Madura, for permitting us to examine their collections. We also thank Mr. Junaidi Mahfudz for his support in collecting plant specimens. We also thank Mr. Junaidi Mahfudz for his support in collecting plant specimens. All authors wrote the manuscript.

\section{REFERENCES}

Ansari P, Debnath M, Ahmad MF, Azam S, Akther S, Mustakim GM, Naquib MH, Sarwar S. 2016. Evaluation of antinociceptive activity of methanol extract from Cleome rutidosperma in Mice. Chinese Herbal Medicines. vol 8(3): 273-279. doi: https://doi.org/10.1016/S1674-6384(16)60050-3.

Aparadh VT, Mahamuni RJ, Karadge BA. 2012. Taxonomy and physiological studies in spider flower (Cleome species): a critical review. Plant Sciences Feed. vol 2(3): 25-46.

Arhoghro EM, Berezi EP, Prohp TP. 2014. Phytochemical constituents and effect of combined ethanolic leaf extract of Costus afer and Cleome rutidosperma on lipid profile and some haematological parameters in Wister rats. International Journal of Current Microbiology and Applied Sciences. vol 3(5): 673-679.

Backer CA, Bakhuizen van den Brink Jr. RC. 1963. Flora of Java (Spermatophytes only). Vol. I : Gymnospermae, families 1-7; Angiospermae, families 8-110. Groningen: N.V.P. Noordhoff
Backer CA, Bakhuizen van den Brink Jr. RC. 1965. Flora of Java (Spermatophytes only). Vol. II : Angiospermae, families 111-190. Groningen: N.V.P. Noordhoff

Ciccarelli D, Andreucci AC, Pagni AM, Garbari F. 2005. Structure and development of the elaiosome in Myrtus communis L.(Myrtaceae) seeds. FloraMorphology, Distribution, Functional Ecology of Plants. vol 200(4): 326-331. doi: https://doi.org/10.1016/j.flora.2004.12.004.

de Castro TC, Simões-Gurgel C, Ribeiro IG, Coelho MGP, Albarello N. 2014. Morphological aspects of fruits, seeds, seedlings and in vivo and in vitro germination of species of the genus Cleome. Journal of Seed Science. vol 36(3): 326-335. doi: https://doi.org/10.1590/2317-1545v36n31013.

Ding HY, Wu PS, Wu MJ. 2016. Cleome rutidosperma and Euphorbia thymifolia suppress inflammatory response via upregulation of phase II enzymes and modulation of NF- $\kappa \mathrm{B}$ and JNK activation in LPSstimulated BV2 microglia. International Journal of Molecular Sciences. vol 17(9): 1-15. doi: https://doi.org/10.3390/ijms17091420

Djarwaningsih T. 2002a. Proses pengepresan contoh tumbuhan. In: Djarwaningsih $\mathrm{T}$, Sunarti $\mathrm{S}$, Kramadibrata K (eds.). Panduan pengolahan dan pengelolaan material herbarium serta pengendalian hama terpadu di Herbarium Bogoriense. Bogor: Herbarium Bogoriense, Pusat Penelitian BiologiLIPI. pp. 1-5.

Djarwaningsih T. 2002b. Pengeplakan material herbarium. In: Djarwaningsih $\mathrm{T}$, Sunarti S, Kramadibrata K (eds.). Panduan pengolahan dan pengelolaan material herbarium serta pengendalian hama terpadu di Herbarium Bogoriense. Bogor: Herbarium Bogoriense, Pusat Penelitian BiologiLIPI. pp. 7-10.

Flathe H, Pfeiffer D. 1963. Outlines on the hydrology of the isle of Madura (Indonesia). In Subterranean Water. Proceeding of the General Assembly of Berkeley. Wallingford: IAHS Press. 64: 543-560.

Forest F, Madden D. 2011. DNA to Darwin case study: Elaiosomes and seed dispersal by ants. Reading: NCBE, University of Reading. pp: 1-6.

Handel SN. 1976. Dispersal ecology of Carex pedunculata (Cyperaceae), a new North American myrmecochore. American Journal of Botany. vol 63(8): 1071-1079. doi: https://doi.org/10.1002/j.15372197.1976.tb13191.x.

Hefni M. 2008. Local knowledge masyarakat Madura: sebuah strategi pemanfaatan ekologi tegal di Madura. KARSA: Journal of Social and Islamic Culture. vol 14(2): 131-141. doi: http://dx.doi.org/10.19105/karsa.v14i2.121.

Iltis HH. 1960. Studies in the Capparidaceae-VII old world Cleomes adventive in the new world. Brittonia. vol 12(4): 279-294. doi: https://doi.org/10.2307/2805120. 
Inda LA, Torrecilla P, Catalán P, Ruiz-Zapata T. 2008. Phylogeny of Cleome L. and its close relatives Podandrogyne Ducke and Polanisia Raf.(Cleomoideae, Cleomaceae) based on analysis of nuclear ITS sequences and morphology. Plant Systematics and Evolution. vol 274(1-2): 111-126. doi: https://doi.org/10.1007/s00606-008-0026-y.

Irsyam ASD. 2015. Kajian floristik suku Rutaceae di kawasan Madura. [Thesis]. Bogor: IPB University.

Irsyam ASD, Chikmawati T. 2015. Peninjauan ulang marga Citrus (Rutaceae) di Kawasan Madura. Floribunda. vol 5(3): 82-91. doi: http://dx.doi.org/10.32556/floribunda.v5i3.2015.3.

Jacobs M. 1960. Flora Malesiana Series I: Seed Plant vol. 6(1). Capparidaceae. Bogor: Foundation Flora Malesiana. pp. 102-103.

Koteyeva NK, Voznesenskaya EV, Roalson EH, Edwards GE. 2011. Diversity in forms of $\mathrm{C}_{4}$ in the genus Cleome (Cleomaceae). Annals of Botany. vol 107(2): 269-283.

doi: https://doi.org/10.1093/aob/mcq239.

Leung WTW, Busson F, Jardin C. 1968. Food composition table for use in Africa. Rome: FAO. p. 306.

Lisci M, Bianchini M, Pacini E. 1996. Structure and function of the elaiosome in some angiosperm species. Flora. vol 191(2): 131-141. doi: https://doi.org/10.1016/S0367-2530(17)30704-1.

Mayer V, Olzant S, Fischer RC. 2005. Myrmecochorous Seed Dispersal in Temperate Regions. In Seed fate: predation, dispersal, and seedling establishment. Wallingford: CABI Publ. pp. 175-196.

Mondal S, Suresh P. 2012. Wound healing activity of Cleome rutidosperma DC. roots. International Current Pharmaceutical Journal. vol 1(6): 151154. doi: https://doi.org/10.3329/icpj.v1i6.10536.

Nguyen TP, Mai DT, Do THT, Phan NM. 2017. Flavonoids with hepatoprotective activity from the leaves of Cleome chelidonii. Natural Product Communications. vol 12(7): 1061-1063. doi: https://doi.org/10.1177\%2F1934578X1701200715.

Okoro IO, Umar IA, Atawodi SE, Anigo KM. 2014. Antidiabetic effect of Cleome rutidosperma DC and Senecio biafrae (Oliv. \& Hiern) extracts in streptozotocin-induced diabetic rats. International Journal of Pharmaceutical Sciences and Research. vol 5(6): 2480-2497. doi: https://doi.org/10.13040/IJPSR.09758232.5(6).2480-97.

Okoro IO, Umar IA, Atawodi SE, Anigo KM. 2015. Bioassay-guided evaluation of the antidiabetic activity of Cleome rutidosperma DC. International Journal of Pharmacy and Pharmaceutical Sciences. vol 7(1): 198-202.

Parimalakrishnan S, Dey A, Smith AA, Manavalan R. 2007. Evaluation of anti-inflammatory, antinociceptive and antipyretic effects of methanol extract of Cleome chelidonii. International Journal of Biological and Chemical Sciences. vol 1(3): 223 228. doi: https://doi.org/10.4314/ijbcs.v1i3.39717.
Royal Botanic Gardens Kew. 2019. Plants of the World Online. Richmond: Royal Botanic Gardens, Kew. http://www.plantsoftheworldonline.org/.

Prabha SB, Rao M, Ramesh KMR. 2017. Evaluation of in vitro Antioxidant, Antibacterial and Anticancer activities of leaf extracts of Cleome rutidosperma. Research Journal of Pharmacy and Technology. vol 10(8): 2492-2496.

http://dx.doi.org/10.5958/0974360X.2017.00440.1.

Rifai MA. 2007. Manusia Madura: Pembawaan, perilaku, etos kerja, penampilan, dan pandangan hidupnya seperti dicitrakan peribahasanya. Yogyakarta: Pilar Media. p.127.

Rugayah, Retnowati A, Windadri FI and Hidayat A. 2004. Pengumpulan Data Taksonomi. In: Rugayah, Widjaja EA, Praptiwi (eds.). Pedoman pengumpulan data keanekaragaman flora. Bogor: Pusat Penelitian Biologi-LIPI. pp. 5-42.

Setiawan AB, Ariyanti NS. 2019. Ciri Anatomi untuk Identifikasi Jenis-jenis Eleocharis (Cyperaceae) Pulau Madura. Floribunda. vol 5(8): 291-298. doi: http://dx.doi.org/10.32556/floribunda.v5i8.2018.22 2.

Spaggiari CV, Smithies RH, Kirkland CL, Wingate MT, England RN, Lu YJ. 2018. Buried but preserved: The Proterozoic Arubiddy Ophiolite, Madura Province, Western Australia. Precambrian Research. vol 317: 137-158. doi: https://doi.org/10.1016/j.precamres.2018.08.025

Sridhar N, Kiran BVVSS, Sasidhar DT, Kanthal LK. 2014. In vitro antimicrobial screening of methanolic extracts of Cleome chelidonii and Cleome gynandra. Bangladesh Journal of Pharmacology. vol 9(2): 161-166. doi: https://doi.org/10.3329/bjp.v9i2.17759.

Tjitrosoedirdjo SS, Tjitrosemito S, Mawardi I, Setiabudi, Suminah N, Pudjantoro. 2007. Pengembangan Database Tumbuhan Asing invasive di Indonesia (Fase II). SEAMEO BIOTROP's Research Grant. Bogor: SEAMEO BIOTROP.

Uhlig H. 1980. Man and tropical karst in Southeast Asia. GeoJournal. vol 4(1): 31-44.

Umiyah. 2011. Pemanfaatan Beberapa Tumbuhan Liar Gulma Sebagai Sayuran di Kabupaten Jember. Berkala Penelitian Hayati. vol 17(1): 103-107.

van Balgooy MMJ. 1987. Collecting. In: de Vogel EF (ed). Manual of Herbarium Taxonomy Theory and Practice. Jakarta: UNESCO. pp. 14-19.

van der Pijl L. 1972. Principles of dispersal in higher plants. Berlin: Springer-Verlag. doi: https://doi.org/10.1007/978-3-642-96108-3.

Woodson Jr. RE. 1948. Gynandropsis, Cleome, and Podandrogyne. Annals of the Missouri Botanical Garden. vol 35(2): 139-147. doi: https://doi.org/10.2307/2394390. 